\title{
EFFECT OF THE INHERENT VARIATION IN THE MINERAL CONCENTRATION OF ALFALFA CULTIVARS ON APHID POPULATIONS ${ }^{(1)}$
}

\author{
ALEXANDRE DE ALMEIDA E SILVA ${ }^{(2)}$; ELENICE MOURO VARANDA ${ }^{(3)}$; \\ ANA CÂNDIDA PRIMAVESI ${ }^{(4)}$
}

\begin{abstract}
Plants have inherent variability of mineral content which affects their physiology and consequently the herbivorous insects feeding on them. Besides, insects need considerable amounts of potassium, phosphorus and magnesium in their diets, whereas little calcium, sodium and chloride are required. In this study, the inherent variation on mineral $(\mathrm{Ca}, \mathrm{S}, \mathrm{Mg}, \mathrm{N}, \mathrm{P}, \mathrm{K}$ and also $\mathrm{C}: \mathrm{N}$ ratio) concentrations and aphid (Acyrthosiphon spp., Therioaphis maculata, Aphis craccivora) populations on three alfalfa (Medicago sativa) cultivars (P3; Crioula, the most widely cultivated in Brazil, and CUF 101, an aphid-resistant) were studied between September/1997 and August/1998. A significant variation on mineral concentrations and aphid populations was observed among different sampling times and cultivars. The correlations between $\mathrm{C}: \mathrm{N}$ ratio, $\mathrm{Mg}, \mathrm{N}, \mathrm{P}$ and $\mathrm{S}$ concentrations and aphid density variation suggest that the mineral status affects aphid population dynamics under field conditions.
\end{abstract}

Key words: Aphididae, insecta, nutrients, resistance, plant-insect relation.

\section{RESUMO}

EFEITO DA VARIAÇÃO INATA DA CONCENTRAÇÃO DE MINERAIS EM CULTIVARES DE ALFAFA (MEDICAGO SATIVA) EM POPULAÇÕES DE AFÍDEOS (HEMIPTERA: APHIDIDAE)

As plantas têm variação inata do conteúdo de minerais e seu estado nutricional afeta sua fisiologia cloretos. A variação inata na concentração de minerais ( $\mathrm{Ca}, \mathrm{S}, \mathrm{Mg}, \mathrm{N}, \mathrm{P}, \mathrm{K}$ e também a razão C:N) e na população de afídeos (Acyrthosiphon spp., Therioaphis maculata, Aphis craccivora) em três cultivares de alfafa (M. sativa) - P3; Crioula, as mais cultivadas no Brasil, e CUF 101, resistente a afídeos - foi estudada entre setembro/1997 a agosto/1998 neste trabalho. A concentração de minerais e as populações de pulgões variaram significativamente entre os diferentes períodos de coleta e cultivares. As correlações encontradas entre as concentrações de $\mathrm{Mg}, \mathrm{N}, \mathrm{P}, \mathrm{S}$ e a razão $\mathrm{C}: \mathrm{N}$ e a variação no número de pulgões sugerem que os minerais da planta afetam a dinâmica populacional dos pulgões em campo.

Palavras-chave: Aphididae, insecta, nutrientes, resistência, relação planta-inseto.

$\left({ }^{1}\right)$ Received for publication in May 21, 2004 and accepted in February 25, 2005.

$\left(^{2}\right)$ IPEPATRO, Rodovia Federal 364, km 3,5, 78900-000, Porto Velho (RO), Brasil. E-mail: alealsil_bio@yahoo.com.br

$\left({ }^{3}\right)$ Departamento de Biologia, Faculdade de Filosofia Ciências e Letras de Ribeirão Preto, Universidade de São Paulo, Av. dos Bandeirantes, 3900, 14040-901 Ribeirão Preto (SP), Brasil. E-mail: emvarand@ffclrp.usp.br

(4) Embrapa Pecuária Sudeste, Rodovia Washington Luiz, km 254, 13560-970 São Carlos (SP), Brasil. E-mail: anacan@cppse.embrapa.br 


\section{INTRODUCTION}

The term nutrition involves a qualitative aspect and despite considerable phylogenetic differences and distinct feeding habits, insects have qualitative needs for most nutrients (except for sterols) similar to those of vertebrates.

The main nutritional needs of insects are amino acids, vitamins, minerals, carbohydrates, lipids and sterols, which should be appropriately balanced, especially in the case of the sugar:protein ratio. Another nutritional aspect considers the quantity, i. e., the nutrients effectively ingested, digested, assimilated and converted into tissues during development (DADD, 1985).

Insects have a great variation in their quantitative need for nutrients. This variation may reflect differences in metabolism, as well as accumulated reserves from a previous stage, or association with other organisms which synthesize some nutrients (House, 1962). But some aspects of insect mineral nutrition are not easily studied due to difficulties in manipulating simple radicals in diets (House, 1962, DADD, 1973).

Despite of that, insects need considerable amounts of potassium, phosphorus, magnesium and small amounts of calcium, sodium and chlorides during their development. Minerals are important for ionic balance, membrane permeability and enzyme activation (DADD, 1973).

Mineral concentration is related to nutritional status of plants affecting their physiology and the herbivorous insects that feed on them in positive, neutral or negative ways (DALE, 1988). Several research papers have been published on the effect of mineral use (supplementation or deprivation) and its impact on insect biology (BARKER and TAUBER, 1957; TAYlor et al., 1952; KindLer and Staples, 1970; MAlbry et al., 1997; BusCh and PHelan, 1999; JANSSON and Еквом, 2002). But there is little information on the effect of inherent concentration of minerals on aphid population dynamics under field conditions.

Certain species and cultivars growing under the same conditions may differ in their ability to use mineral elements available in the soil (PAINTER, 1954). Plants also have inherent variability in nutrient levels (MATTSON and SCRIBER, 1987; EASTON et al., 1997). In this work, we investigated the relationships between inherent variation in the $\mathrm{Ca}, \mathrm{S}, \mathrm{N}, \mathrm{Mg}, \mathrm{P}$ and $\mathrm{K}$ concentration of three alfalfa (Medicago sativa) cultivars and variation in aphid populations on these plants in different sampling period.

\section{MATERIAL AND METHODS}

Plant material of each cultivar, P3; Crioula, the most widely cultivated alfalfa cultivar in Brazil; and CUF 101, an aphid resistant cultivar, (replicates from 3 plots of $3 \times 2 \mathrm{~m}$ ) was sampled from September $/ 1997$ to August/1998 (12 samplings-15/09/97; 10/10;10/ $11 ; 08 / 12 ; 05 / 01 / 98 ; 30 / 01 ; 02 / 03 ; 01 / 04 ; 30 / 04 ; 01 /$ 06; 03/07; 07/08), at the pre-bloom stage. The three alfalfa cultivars were cultivated at the Canchim cattle farm of Embrapa (Brazilian Federal Agricultural Research Agency) ( $22^{0} 01^{\prime} \mathrm{S}$ and $\left.47^{0} 54^{\prime} \mathrm{W}\right)$ near São Carlos, São Paulo state, Brazil. The soil was fertilized (180 kg ha ${ }^{-1}$ of $\mathrm{P}_{2} \mathrm{O}_{5} ; 150 \mathrm{~kg} \mathrm{ha}^{-1}$ of $\mathrm{K}_{2} \mathrm{O} ; 30 \mathrm{~kg} \mathrm{ha}^{-1}$ of FTE BR 12; plus $30 \mathrm{~kg} \mathrm{ha}^{-1}$ of $\mathrm{K}_{2} \mathrm{O}$ after each harvest) and the fields were irrigated (15 $\mathrm{mm}$ twice weekly) in the dry season. In June, CUF 101 plant samples were not included in the analysis because of ants damages.

One hundred shoots, collected individually once per sampling from each alfalfa cultivar, were placed in plastic bags ( 1 shoot per bag) and stored in common freezers $\left(-20^{\circ} \mathrm{C}\right)$. A soap solution $(500 \mathrm{~mL})$ was added to each bag, which was then shaken for a few seconds. The shoot was removed and the solution filtered. Aphids retained on the filter were transferred to Petri dishes and the species Therioaphis maculata, Aphis craccivora and Acyrthosiphon spp. were separated and counted using a stereomicroscope and expressed as aphid density. Both species of Acyrthosiphon ( $A$. pisum and $A$. kondoi) were considered as one (Acyrthosiphon spp.) due to difficulties in identifying early instars.

Plant material $(500 \mathrm{~g})$ was dried at $60^{\circ} \mathrm{C}$ in a forced-air drying oven, until constant weight was reached. Each sample was ground in a Wiley-type mill equipped with a 20 mesh sieve (SARRUGE and HAAG, 1974). Nitrogen concentration was determined by a microkjeldahl method (AOAC, 1995), after sulfuric digestion. After nitroperchloric digestion, the calcium and magnesium concentrations were determined by titration with EDTA; phosphorus concentration was determined by colorimetry and potassium by flame photometry (Malavolta et al., 1989). Carbon content was determined after calcination in a muffle furnace at $550^{\circ} \mathrm{C}-600^{\circ} \mathrm{C}$ (SiLva, 1981).

Statistical analyses were performed using Sigma Stat 2.03 (1992-1997 SPSS Inc.). Two-Way ANOVA was used to study the effects of sampling time and cultivar on the concentration of six different minerals and also C: $\mathrm{N}$ ratio (3 replicates/sampling/ cultivar). Nonparametric analyses with two or more factors are not generally acceptable (ZAR, 1999) and therefore ANOVA on Ranks was used to study the variation in the aphid population (100 replicates/ 
sampling/cultivar). Multiple comparisons among data were performed using the Dunn's test. Spearman rank order correlation was used to test for correlation between aphid populations and mineral variation.

\section{RESULTS}

Two Way ANOVA tests indicated differences among mineral concentrations for variables sampling and cultivar, but no significant interaction (sampling $\mathrm{x}$ cultivar) was found.

Mineral concentration in alfalfa cultivars had significant $(\mathrm{p}<0.05)$ variation in different sampling times (Fig. 1). No significant differences were found among phosphorus concentrations during the first five sampling times $(\mathrm{p}<0.001)$, but a significant decrease in the $6^{\text {th }}$ sampling was detected $(\mathrm{p}<0.001)$. After a decrease on the $9^{\text {th }}$ sampling, nitrogen concentration increased significantly $(\mathrm{p}<0.001)$ and was the highest at the $11^{\text {th }}$ sampling. Calcium concentration was the highest in the $1^{\text {st }}$ and $12^{\text {th }}$ samplings $(\mathrm{p}<0.001)$. There was a significant increase in sulfur concentration from the $1^{\text {st }}$ to the $6^{\text {th }}$ samplings $(p<0.001)$. The lowest potassium concentration was found at the $4^{\text {th }}, 5^{\text {th }}, 8^{\text {th }}$ and $12^{\text {th }}$ samplings $(\mathrm{p}<0.001)$. Magnesium concentration was the highest at the $8^{\text {th }}$ sampling $(\mathrm{p}<0.001)$. C:N ratio was the highest from the $1^{\text {st }}$ to the $4^{\text {th }}$ samplings and at the $9^{\text {th }}(\mathrm{p}<0.001)$ (Figure 1$)$.

Phosphorus concentration was the highest in P3 cultivar $(p<0,001) . C: N$ ratio, magnesium and calcium concentrations were the highest in Crioula cultivar ( $p=0,002 ; p<0,001$ and $p=0,003$, respectively). Nitrogen concentration was the highest in CUF 101 $(\mathrm{p}=0,01)$ (Table 1$)$.
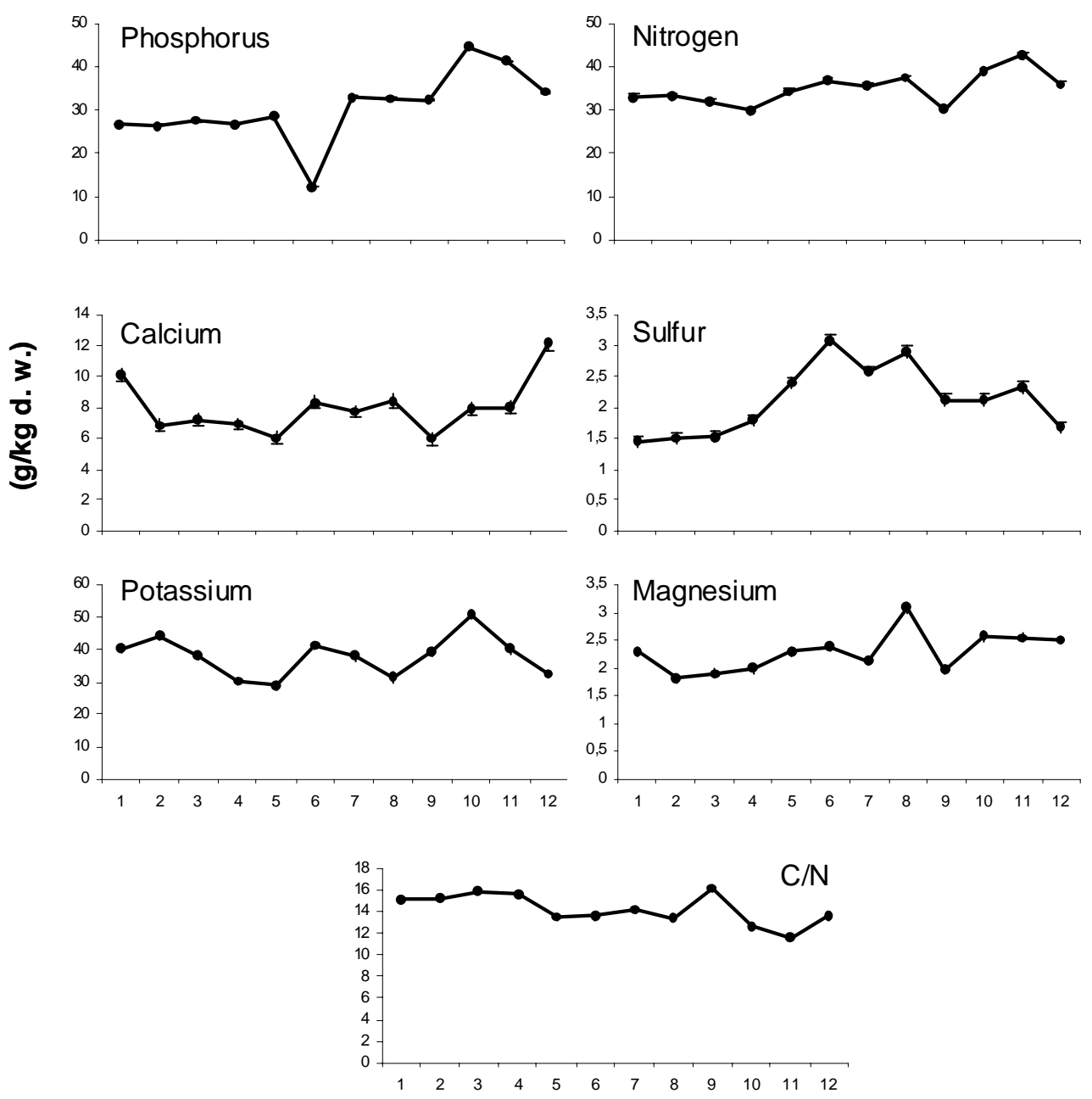

\section{Sampling time}

Figure 1. Variation in the mineral concentrations in alfalfa (Medicago sativa) cultivars on different sampling times. (mean \pm s. e.)

Data for sampling in Two Way Anova (sampling x cultivar). 
Table 1. Concentrations ( $\mathrm{g} \mathrm{kg}^{-1} \mathrm{~d}$. w.) of different minerals in three alfalfa (Medicago sativa) cultivars. (mean \pm s.e.)

\begin{tabular}{|c|c|c|c|}
\hline \multirow{2}{*}{ Mineral } & \multicolumn{3}{|c|}{ Cultivar } \\
\hline & P3 & Crioula & CUF 101 \\
\hline Phosphorus & $33.2 \pm 0.09^{a}$ & $27.6 \pm 0.09^{b}$ & $28.0 \pm 0.09^{b}$ \\
\hline Nitrogen & $34.0 \pm 0.3^{\mathrm{a}}$ & $33.6 \pm 0.3^{\mathrm{a}}$ & $35.2 \pm 0.3^{b}$ \\
\hline Calcium & $7.6 \pm 0.2^{\mathrm{a}}$ & $8.6 \pm 0.2^{b}$ & $7.6 \pm 0.2^{\mathrm{a}}$ \\
\hline Sulfur* & $2.1 \pm 0.04$ & $2.1 \pm 0.04$ & $2.1 \pm 0.04$ \\
\hline Potassium* & $38.3 \pm 0.7$ & $36.3 \pm 0.7$ & $38.5 \pm 0.7$ \\
\hline Magnesium & $2.1 \pm 0.04^{\mathrm{a}}$ & $2.5 \pm 0.04^{\mathrm{b}}$ & $2.2 \pm 0.04^{\mathrm{a}}$ \\
\hline $\mathrm{C}: \mathrm{N}$ & $14.4 \pm 0.1^{\mathrm{a}}$ & $14.9 \pm 0.1^{\mathrm{b}}$ & $13.9 \pm 0.1^{\mathrm{a}}$ \\
\hline
\end{tabular}

* Indicate no significant $(\mathrm{p}>0.05)$ differences for a mineral among cultivars. Different letters indicate significant ( $\mathrm{p}<0.05)$ differences for a mineral in a row. Data for cultivar in Two Way Anova (sampling x cultivar).

There was a significant variation on aphids density on different samplings and cultivars $(p<0.05)$. Acyrthosiphon spp. density was the highest on the 3 rd and $4^{\text {th }}$ samplings and peaked at the $9^{\text {th }}$. The highest density of Acyrthosiphon spp. observed was found on the resistant cultivar CUF 101. Therioaphis maculata density was the highest from the $1^{\text {st }}$ to $3^{\text {rd }}$ samplings and also at the $9^{\text {th }}$ and $12^{\text {th }}$. CUF 101 had the lowest density of this aphid species. Aphis craccivora was found from the $3^{\text {rd }}$ to the $6^{\text {th }}$ samplings and also at the $9^{\text {th }}$ but, it was almost absent at the other samplings. Also, CUF 101 had the lowest density of this aphid species. Total aphid density was high from the $1^{\text {st }}$ to $4^{\text {th }}$ samplings and also at the $9^{\text {th }}$. Total aphid density was usually lower on the resistant cultivar CUF 101 than the others (Figure 2).

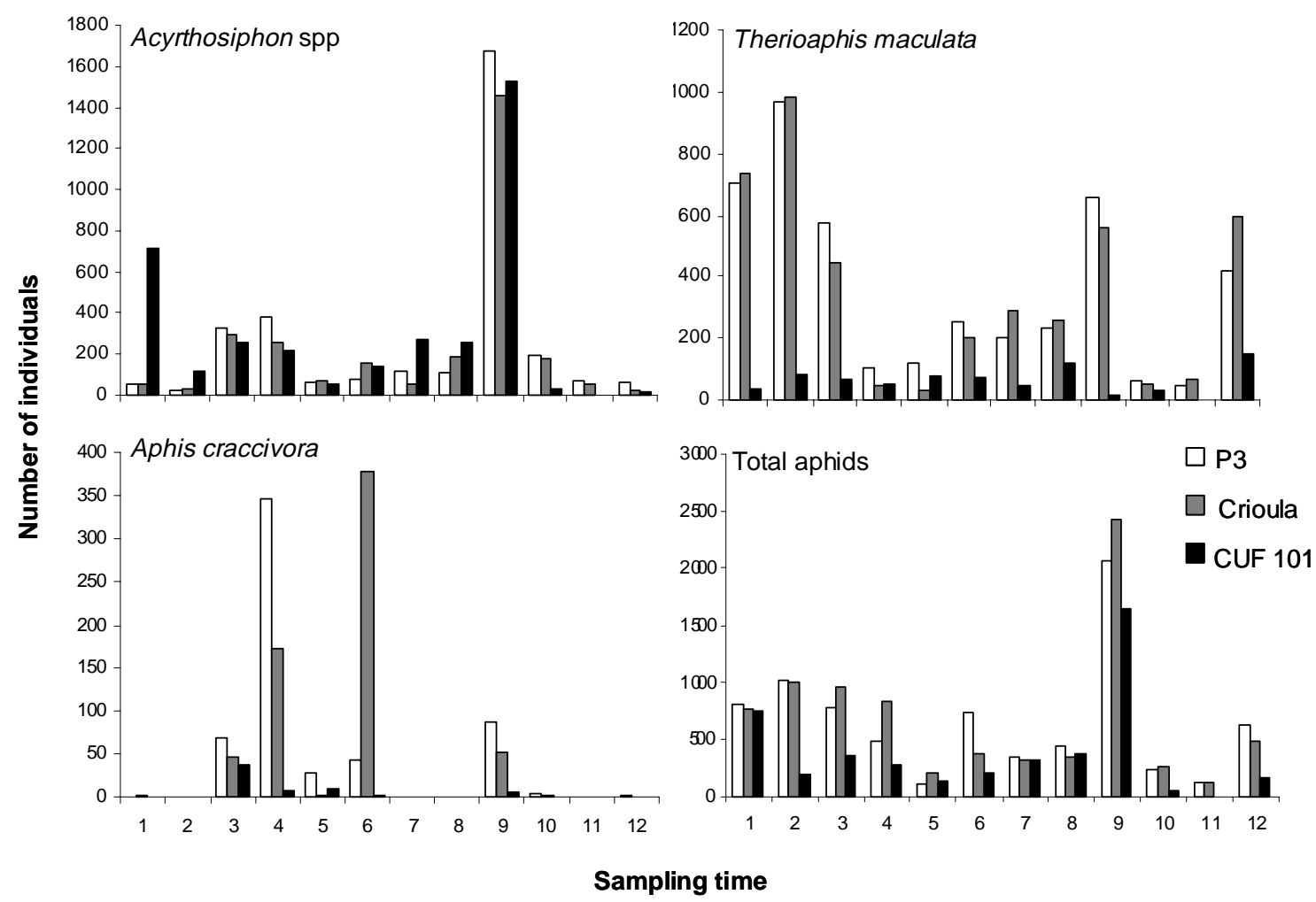

Figure 2. Variation in the aphid populations on three alfalfa (Medicago sativa) cultivars in different sampling times. Anova on Ranks (Kruskal-Wallis test) - 100 replicates. Data presented as total number of individuals in each sampling for each cultivar. 
$\mathrm{C}: \mathrm{N}$ ratio was positively correlated to the variation of Acyrthosiphon spp. and T. maculata populations $(\mathrm{r}=0.6, \mathrm{p}=0.03 ; \mathrm{r}=0.63, \mathrm{p}=0.02$, respectively) and also to total aphid density variation on all cultivars (Crioula- $\mathrm{r}=0.9, \mathrm{p}<0.001$; P3- $\mathrm{r}=0.8$, $\mathrm{p}<0.001$ and CUF 101- $\mathrm{r}=0.6, \mathrm{p}=0.03$ ). There was a negative correlation between nitrogen and magnesium concentrations and total aphids density on $\mathrm{P} 3$ and Crioula (N- $\mathrm{r}=-0.63, \mathrm{p}=0.02 ; \mathrm{r}=-0.79, \mathrm{p}<0.001 ; \mathrm{Mg}-$ $\mathrm{r}=-0.59, \mathrm{p}=0.04 ; \mathrm{r}=-0.7, \mathrm{p}=0.009$; respectively). Total aphid density on P3 was also negatively correlated to phosphorus concentration $(\mathrm{r}=-0.63 ; \mathrm{p}=0.03)$ and total aphid density on Crioula was negatively correlated to sulfur concentration $(r=-0.58 ; \mathrm{p}=0.04)$.

\section{DISCUSSION}

Mineral analysis of alfalfa plant tips in this work was made during the pre-bloom stage and therefore, the mineral variation found was not related to growth stage. Despite of that, ABRAHAMSON and Mc CREA (1985) found that most seasonal changes in the nutrient content and also the highest mineral content in Solidago altissima were associated with young, actively growing plant parts and inflorescences. AIAZZI et al. (1999) found that seasonal differences in the mineral content of Atriplex cordobenses were related to the growth stage (vegetative or reproductive) with accumulation of some minerals in the reproductive structures. As the alfalfa cultivars had a very short cycle between vegetative and reproductive stages (about 30 days), so the observed variation in the mineral concentration during pre-bloom might have resulted from factors affecting soil mineral uptake on different samplings.

Significant differences in mineral concentration among different alfalfa cultivars were found in this work (Tab. 1), which implies genotypic differences among cultivars. EASTON et al. (1997) reported genetic variation in the concentration of macro and micro minerals in ryegrass (Lolium perene).

Mineral status affects plant's physiology and the herbivores feeding on them, but mineral ions are also important to insect's physiology in at least three major processes: enzyme activation $(\mathrm{K}, \mathrm{Mg}, \mathrm{Fe}, \mathrm{Co}$, $\mathrm{Mn})$, trigger and control mechanisms $(\mathrm{Na}, \mathrm{Ca}, \mathrm{K})$, and structure formation $(\mathrm{Mg})$. Insect's tissues have large quantities of three major mineral elements: $\mathrm{P}(10 \mathrm{~g} \mathrm{~kg}$ ${ }_{1}^{1}$ d.w. $), K\left(1 \mathrm{~g} \mathrm{~kg}^{-1}\right.$ d.w.) and $M g\left(2 \mathrm{~g} \mathrm{~kg}^{-1}\right.$ d.w. $)$ Therefore, it is expected that herbivore interaction with host plants would be at least partially mediated by an interaction between minimal optimum nutrient requirements and the inherent variability of the plant contents of these nutrients (MATTSON and SCRIBER, 1987).
Several investigators (AUClaIR, 1965; DADD and Mittler, 1965; DadD, 1967; AKey and BeCK, 1972; Auclair and SRIVASTAVA, 1972) did show that macro and micro minerals are essential for aphid development, affecting significantly their biology on artificial diets. Mineral concentrations above optimum thresholds are usually toxic to aphids, e. g., high boron and molybdenum (Auclair and SRIVASTAVA, 1972), phosphorus and potassium (Auclair, 1965) to $A$. pisum; magnesium to A. pisum (AuClaIr, 1965) and M. persicae (DADD and MitTLER, 1965) and nitrate to $S$. graminum (SALAS et al., 1990)

The concentration of individual minerals (e.g., $\mathrm{P}, \mathrm{Mg}, \mathrm{S})$, also their ratios in alfalfa tissues, was negatively correlated to aphid population variation in the present work, suggesting that they affected aphid biology. JANSSON and Еквом (2002) found negative correlations between both magnesium and sulfur concentration in Petunia leaves and fecundity and longevity of the aphid Macrosiphum euphorbiae and BusCH and Phelan (1999) found that high phosphorus concentrations in soybeans resulted in longer developmental time of soybean looper (Pseudoplusia includens) and mineral proportions, such as high P:S ratio decreased pupal mass of this insect, but the opposite response was measured with a high S: P ratio.

In this work, a positive correlation of $\mathrm{C}: \mathrm{N}$ ratio and a negative correlation of $\mathrm{N}$ between aphid population were found. TRIPP et al. (1992) related fewer whiteflies on tomatoes with high $\mathrm{C}: \mathrm{N}$ ratios. A decline on the performance of the aphids M. euphorbiae and Myzus persicae was found on potato tuber-filling leaves with a high $C: N$ ratio, but $C: N$ ratio on leaves was not correlated to sugar: amino acid ratio (KARLEY et al., 2002). Although most sucking insects respond positively to $\mathrm{N}$ fertilization (JANSSON and Еквом, 2002), after reviewing several papers on $\mathrm{N}$ supplementation, VAN EMDEN (1966) related that in 36\% of the cases aphids responded negatively to $\mathrm{N}$ fertilization, e.g., on barley (SAlas et al., 1990) and Polygonum pensilvanicum (MALBRY et al., 1997).

SAlas et al. (1990) related nitrogen supplementation was positively related to alkaloid (gramine) concentration and was negatively correlated to aphid (Schizaphis graminum) performance on barley. Alkaloids are also present in alfalfa (CONNOR et al., 1973; Phillips et al., 1992; Wiehler and Marion, 1958) and are known to be related to root symbiont biochemical and ecological relations on alfalfa (Phillips et al., 1992). Present data, supported by negative correlations between aphid density and nitrogen concentration, highlights a possible relation between alkaloids and aphids on alfalfa. A significant higher concentration of nitrogen on the aphid resistant cultivar was also detected. 
No significant correlations between aphid population variation and minerals, except for $\mathrm{C}: \mathrm{N}$ ratio, were found for the resistant cultivar CUF 101, possibly due to its negative effect on T. maculata population size. Busch and PHELAN (1999) argued that responses to mineral concentration varied within species, also within cultivars, and were speciesspecific such as found in this work.

That would explain differences in the results of different researches on mineral effect on the same plant and aphid species, e.g., peas and pea aphids (BARKER and TAUBER, 1957 and TAYLOR et al., 1952).

Interestingly, the number of Acyrthosiphon spp. on the resistant cultivar was as high as or even higher than in the susceptible cultivars. Apparently, Acyrthosiphon spp. overcomes the resistant characteristics of CUF 101. The existence of "resistant" A. pisum (Bournoville et al., 2000) and A. kondoi (ZARRABI et al., 1995) biotypes to CUF 101 was already reported.

Undoubtedly, there are other factors affecting aphid population dynamics in alfalfa under field conditions such as climatic conditions, mainly, temperature and rain (BERBERET et al., 1983; CARVALHO et al., 1996) and also qualitative changes induced by crowding that are the most probable regulating factor for aphid populations according to DIXON (1977).

Correlations found between inherent mineral concentration and aphid populations on alfalfa suggest that mineral variation is related to aphid population dynamics under field conditions. Whether minerals affect aphid biology directly or indirectly through their effect on plant physiology remains to be determined.

\section{CONCLUSIONS}

1. Mineral concentration and aphid abundance in alfalfa vary with sampling time and cultivar.

2. Variation in aphid abundance along different sampling times is correlated to C: $\mathrm{N}$ ratio, $\mathrm{N}, \mathrm{Mg}, \mathrm{P}$ and $\mathrm{S}$, but correlations vary with cultivar and aphid species.

\section{ACKNOWLEDGEMENTS}

The authors thank CAPES for financial support and Dr. Pitágoras da Conceição Bispo for statistical debates.

\section{REFERENCES}

ABRAHAMSON, W.G.; MCCREA, K.D. Seasonal nutrient dynamics of Solidago altissima (Compositae). Bulletin of the Torrey Botanical Club, New York, v.112, n.4, p.414-420, 1985.

AIAZZI, M.T.; ABRIL, A.; TORRES, P.; DI RIENZO, J.A.; ARGUELLO, J.A.. Seasonal variations in chemical composition of leaves and stems of Atriplex cordobensis (Gandoger et Stuckert), female and male plants. Phyton, Buenos Aires, v.65, p 173-178, 1999.

AKEY, D.H.; BECK, S.D. Nutrition of the pea aphid, Acyrthosiphon pisum: requirements for trace metals, sulphur, and cholesterol. Journal of Insect Physiology, London, v.18, p.1901-1914, 1972.

ASSOCIATION OF OFFICIAL AGRICULTURAL CHEMISTS AOAC. Official methods of analysis. Arlington, Virginia, 1995.

AUCLAIR, J. L. Feeding and nutrition of the pea aphid, Acyrthosiphon pisum (Homoptera: Aphididae), on chemically defined diets of various $\mathrm{pH}$ levels and nutrient levels. Annals of the Entomological Society of America, Columbus, v.58, p. 855-875, 1965.

AUCLAIR, J.L.; SRIVASTAVA, P.N. Some mineral requirements of the pea aphid, Acyrthosiphon pisum (Homoptera: Aphididae). Canadian Entomologist, Ottawa, v.104, p. 927-936, 1972.

BARKER, J. S.; TAUBER, O. E. Fecundity of and plant injury by the pea aphid as influenced by nutritional changes in the garden pea. Journal of Economic Entomology, College Park, v.44, p. 1010-1012, 1957.

BERBERET, R. C.; ARNOLD, D. C.; SOTERES, K. M. Geographical occurrence of Acyrthosiphon kondoi Shinji in Oklahoma and its seasonal incidence in relation to Acyrthosiphon pisum (Harris), and Therioaphis maculata (Buckton) (Homoptera: Aphididae). Journal of Economic Entomology, College Park, v.76, n.5, p.1064-1068, 1983

BOURNOVILLE, R.; SIMON, J. C.; BADENHAUSSER, I; GIROUSSE, C.; GUILLOUX, T.; ANDRÉ, S. Clones of pea aphid, Acyrthosiphon pisum, (Hemiptera: Aphididae) distinguished using genetic markers, differ in their damaging effect on resistant alfalfa cultivar. Bulletin Entomological Research, London, v. 90, p. 33-39, 2000.

BUSCH, J. W.; PHELAN, P. L. Mixture models of soybean growth and herbivore performance in response to nitrogen-sulfurphosphorous nutrient interactions. Ecological Entomology, London, v.24, p. 132-145, 1999.

CARVALHO, A. R.; BUENO, V. H. P.; MENDES, S. Influência de fatores climáticos e do corte na flutuação populacional de pulgões (Homoptera: Aphididae) na cultura da alfafa (Medicago sativa L.), em Lavras, MG. Pesquisa Agropecuária Brasileira, Brasília, v.31, p. 317-324, 1996.

CONNOR, M. A.; STARK, J. B.; FRITZ, J. C.: KOHLER, G. O. Stachydrine: content in alfalfa and biological activity in chicks. Journal of Agriculture and Food Chemistry, Washington, v.21, n.2, p. 195-198,1973. 
DADD, R. H. Improvement of synthetic diet for the aphid Myzus persicae using plant juices, nucleic acids, or trace minerals. Journal of Insect Physiology, London, v.13, p. 763778. 1967.

DADD, R. H. Nutrition: organisms. In: KERKUT, G. A.; GILBERT, L. I. (Ed.). Comprehensive insect physiology, biochemistry and pharmacology. Oxford: Pergamon Press, 1985. p. 310-390.

DADD, R. H. Insect nutrition: current developments and metabolic implications. Annual Review of Entomology, Palo Alto, v.18, p. 381-420, 1973.

DADD, R. H.; MITTLER, T. E. Studies on the artificial feeding of the aphid Myzus persicae (Sulzer)- III. Some major nutritional requirements. Journal of Insect Physiology, London, v. 11, p. 717-743, 1965.

DALE, D. Plant mediated effects of soil mineral stresses on insects. In: HEINRICHS, E.A. (Ed.). Plant-stress-insect interactions. New York: John Wiley \& Sons, 1988. p.35-110.

DIXON, A. F. G. Aphid ecology: life cycles, polymorphism, and population regulation. Annual Review of Ecology and Systematics, Palo Alto, v.8, p.329-353, 1977.

EASTON, H. S.; MACKAY, A. D.; LEE, J. Genetic variation for macro- and micro-nutrient concentration in perennial ryegrass (Lolium perene L.). Australian Journal of Agricultural Research, East Melbourne, v.48, p. 657-666, 1997.

EMDEN, H. F. VAN. Studies on the relations of insect and host plant. III. A comparison of the reproduction of Brevicoryne brassicae and Myzus persicae: (Hemiptera: Aphididae) on brussels sprouts plants supplied with different rates of nitrogen and potassium. Entomologia Experimentalis et Applicata, Amsterdam, v.9, p.444-460, 1966.

HOUSE, H. L. Insect nutrition. Annual Review of Biochemistry, Palo Alto, v. 31, p. 653-672, 1962.

JANSSON, J.; EKBOM, B. The effect of different plant nutrient regimes on the aphid Macrosiphum euphorbiae growing on petunia. Entomologia Experimentalis et Applicata, Amsterdam, v.104, p. 109-116, 2002.

KARLEY, A. J.; DOUGLAS, A. E.; PARKER, W. E. Amino acid composition and nutritional quality of potato leaf phloem sap for aphids. Journal of Experimental Biology, Cambridge, v. 205, p.3009-3018, 2002.

KINDLER, S. D.; STAPLES, R. Nutrients and reaction of two alfalfa clones to the spotted alfalfa aphid. Journal of Economic Entomology, College Park. v. 63, p. 438-440, 1970.
MALAVOLTA, E.; VITTI, G. C.; OLIVEIRA, S. A. Avaliação do estado nutricional das plantas: Princípios e aplicações. Piracicaba: Associação Brasileira para pesquisa de potássio e fosfato, 1989. 201p.

MALBRY, C. M.; JASIENSKI, M.; COLEMAN, J. S.; BAZZAZ, F. A. Genotypic variation in Polygonum pensylvanicum: nutrient effects on plant growth and aphid infestation. Canadian Journal of Botany, Otawa, v.75, p.546-551, 1997.

MATTSON, W. J.; SCRIBER, J. M. Nutritional ecology of insect folivorous of wood plants: nitrogen, water, fiber and mineral considerations. In: SLANKY Jr, F.; RODRIGUEZ, J.G. (Eds.). Nutritional ecology of insects, mites, spiders and related invertebrates. New York: John Wiley \& Sons, 1987. p.105-146.

PAINTER, R. Some ecological aspects of the resistance of crop plants to insects. Journal of Economic Entomology, College Park, v.47, p.1026-1040, 1954.

PHILLIPS, D. A.; JOSEPH, C. M.; MAXWELL, C. A. Trigonelline and stachydrine released from alfalfa seeds activate NodD2 protein in Rhizobium meliloti. Plant Physiology, Rockville, v.99, p. 1526-1531, 1992.

SALAS, M. L.; CORCUERA, L. J.; ARGANDONA, V. H. Effect of potassium nitrate on gramine content and resistance of barley against the aphid Schizaphis graminum. Phytochemistry, Oxford, v.29, n.12, p. 3789-3791, 1990.

SARRUGE, J. R.; HAAG, H. P. Análises químicas em plantas. Piracicaba: ESALQ-USP, 1974, 56p.

SILVA, D. J. Análise de alimentos: métodos químicos e biológicos. Viçosa :UFV, 1981. 166p.

TAYLOR, L.F., APPLE, J.W.; BERGER, K.C. Response of certain insects to plants grown on varying fertility levels. Journal of Economic Entomology, College Park, v.45, n.5, p.843-848, 1952.

TRIPP, K. E.; KROEN, W. K.; PEET, M. M.; WILLITS, D. H. Fewer whiteflies found on $\mathrm{CO}_{2}$-enriched greenhouse tomatoes with high C:N ratios. HortScience, Alexandria, v.27, n.10, p. 1079-1080, 1992

WIEHLER, G.; MARION, L. Homostachydrine, a new alkaloid isolated from seeds of Medicago sativa L. Grimm. Canadian Journal of Chemistry, Otawa, v. 36, p. 339-343, 1958.

ZAR, J. H. Bioestatistical analysis. $4^{\text {th }}$ ed. New Jersey: PrenticeHall, 1999. 660p.

ZARRABI, A. A.; BERBERET, R. C.; CADDEL, J. L. New biotype of Acyrthosiphon kondoi (Homoptera: Aphidadae) on alfalfa fields in Oklahoma. Journal of Economic Entomology, College Park, v.88, n.5, p. 1461-1465, 1995. 